\title{
MONTE CARLO SIMULATION OF THz FREQUENCY GUNN EFFECT IN GaAs MOSFET WITH EXCESS OF ELECTRONS IN CHANNEL AT IMPACT IONIZATION CONDITIONS
}

\author{
V. Gružinskis, E. Starikov, and P. Shiktorov \\ Semiconductor Physics Institute, Center for Sciences and Technology, LT-01108 Vilnius, Lithuania \\ E-mail: viktor@pav.pfi.lt
}

Received 18 November 2013; accepted 4 December 2013

\begin{abstract}
The results of Monte Carlo simulation of GaAs MOSFETs under impact ionization conditions in the conduction channel are presented. The main attention is paid to the transistor operation at a positive gate bias when the electron concentration in the channel under the gate considerably exceeds the channel doping level. The stationary characteristics including current voltage relation and velocity, energy and field profiles in the channel are calculated. Also, the drain current noise spectra at various drain biases are presented. The Gunn-effect dynamics in excess of electrons in the channel is investigated. The optimization of transistor geometrical, doping, and biasing parameters for high frequency generation is performed. It is shown that GaAs MOSFET can generate at $325 \mathrm{GHz}$ frequency.
\end{abstract}

Keywords: terahertz, field-effect transistor, impact ionization, Gunn effect, GaAs

PACS: $72.20 . \mathrm{Ht}, 72.30 .+\mathrm{q}, 73.63 . \mathrm{Hs}$

\section{Introduction}

The Thz technology gained great interest due to its potential application in radio astronomy, remote sensing, commercial imaging, biomedicine and other areas. The most important element in modern Thz technology is a generator of coherent $\mathrm{THz}$ radiation. Semiconductor sources are of great interest due to compact sizes and possibility to be integrated into a single chip. The most common source is the Gunn device. The increase of generation frequency of these devices can be achieved only by device size reduction, which in turn leads to the appearance of a very high electric field inside the device during the operation. In such conditions, the impact ionization can lead to uncontrolled growth of current which can result in inevitable breakdown of the device. From this point of view, the upper frequency limit of the stationary Gunn effect in the FET devices is of a great interest.

The Gunn effect at impact ionization conditions in GaAs MESFET is simulated by Monte Carlo particle (MCP) technique [1]. The $125 \mathrm{GHz}$ drain current oscillations are demonstrated. Also, the $50 \mathrm{GHz}$ drain current oscillations at impact ionization conditions in AlGaAs/InGaAs HEMTs are shown by MCP technique [2]. The aim of this article is to simulate the current transport in GaAs MOSFETs at impact ionization conditions and by proper choice of structure parameters and biasing conditions to obtain the highest drain current oscillation frequency due to the Gunn effect.

\section{Model}

Below we present the calculations of electron-hole transport in the MOSFET structure based on 50$320-50 \mathrm{~nm} \mathrm{n}{ }^{+} n^{+}$GaAs channel with the width of $200 \mathrm{~nm}$. The $200 \mathrm{~nm}$ long gate is placed in n-region at a distance of $80 \mathrm{~nm}$ from $\mathrm{n}^{+}$source. The doping for $\mathrm{n}$ is $5 \cdot 10^{16} \mathrm{~cm}^{-3}$ and for $\mathrm{n}^{+}$it is $10^{19} \mathrm{~cm}^{-3}$.

The MCP simulations were performed by simultaneous solution of coupled Boltzmann and pseudo-2D Poisson [3] equations. In the pseudo-2D Poisson equation, effective distance between the gate and channel is set to be $100 \mathrm{~nm}$. The bipolar GaAs model consists of three conduction ( $[-\mathrm{L}-\mathrm{X}$ ) [ [4] and two valence (heavy hole and spin-orbit split-off) bands [5]. Also, the model includes impact ionization using the Keldysh formula, carrier lifetimes (20 ns for electrons and $4 \mathrm{~ns}$ for holes) and Auger recombination with the same coefficient for electrons and holes $C=10^{-28} \mathrm{~cm}^{6} \mathrm{~s}^{-1}[6]$. The lattice temperature in all cases is $300 \mathrm{~K}$. The number of simulated particles is up to 400,000 and time step is $0.5 \mathrm{fs}$.

\section{Numerical results}

The number of simulations was performed in the structures with different geometrical, doping, and biasing 
parameters to get the maximum drain current oscillation frequency. The above presented structure is optimal for such oscillations. Figure 1 shows the drain current and impact ionization intensity dependencies on the drain bias in the structure when gate bias $U_{\mathrm{g}}=25 \mathrm{~V}$.

The avalanche breakdown in the structure occurs at the drain bias over $4.05 \mathrm{~V}$ while impact ionization processes start over $2.6 \mathrm{~V}$. The drain current starts to grow at the drain voltage of $3.8 \mathrm{~V}$ when impact ionization intensity is sufficiently high. Therefore, from the current-voltage relation it is difficult to identify the beginning of impact ionization processes. Drain currents as functions of time at different drain biases are demonstrated in Fig. 2 .

From bottom to top: drain bias $U_{\mathrm{d}}=2,3$, and $4 \mathrm{~V}$. To avoid overlap, the curves are shifted by $0,0.5$, and $1.5 \cdot 10^{9} \mathrm{Am}^{-2}$.

One can see the low amplitude drain current oscillations in Fig. 2 at $U_{d}=3 \mathrm{~V}$ when impact ionization is negligible (see Fig. 1). The high amplitude oscillations arise at $U_{\mathrm{d}}=4 \mathrm{~V}$. In this case, the impact ionization processes are intensive. The high drain current oscil-

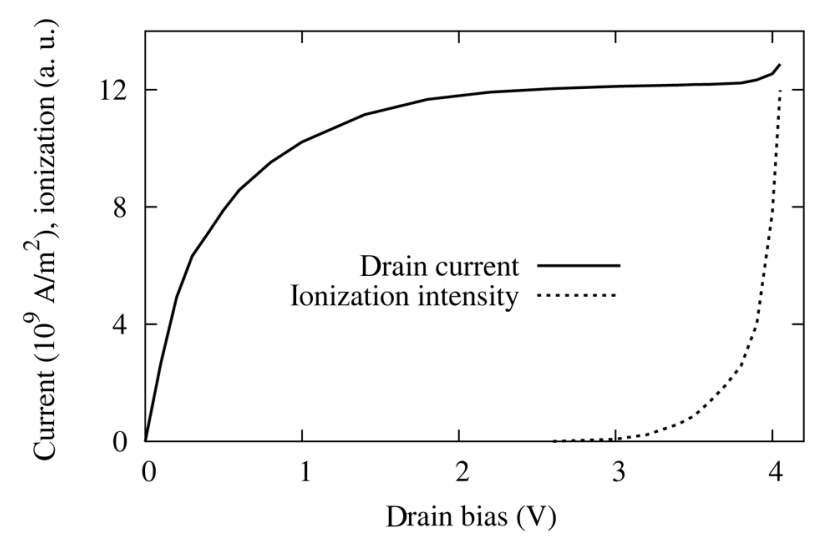

Fig. 1. Drain current and impact ionization intensity as functions of drain bias at $U_{\mathrm{g}}=25 \mathrm{~V}$.

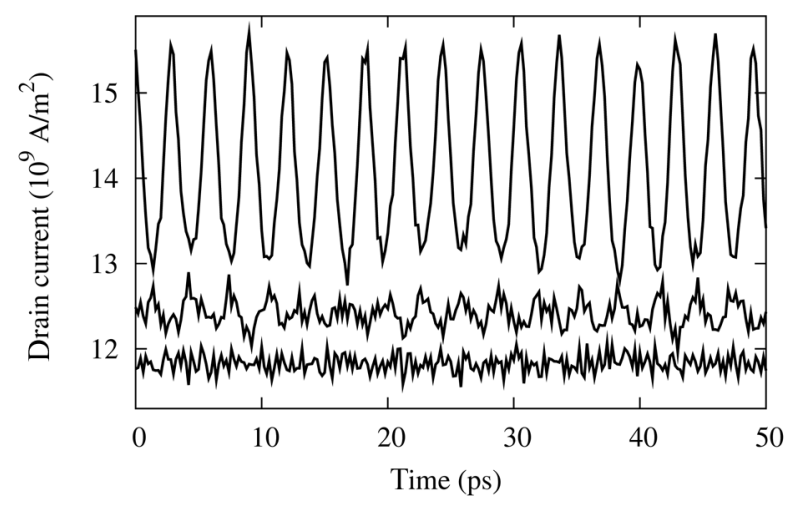

Fig. 2. Drain currents as functions of drain bias at $U_{\mathrm{g}}=25 \mathrm{~V}$. lation amplitude arises due to the impact ionization and Gunn domain motion synchronization. The maximum current and impact ionization event number are achieved when the Gunn domain enters the drain contact. The drain current noise spectral densities at different drain biases are demonstrated in Fig. 3 .

For more detailed analysis of the processes in the channel, the average concentration, velocity and field profiles at the drain bias of $4 \mathrm{~V}$ are shown in Fig. 4 .

The fundamental drain current oscillation peak at $325 \mathrm{GHz}$ frequency is evident (Fig. 3). Moreover, at the drain bias of $4 \mathrm{~V}$, the peaks corresponding to second and third harmonics can be seen. In this case, the enhanced low-frequency noise appears, which comes from the hole component of the current. Due to the high effective masses and low velocity in the channel (Fig. 4(b)), holes have no effect on fundamental peak frequency (compare $3 \mathrm{~V}$ and $4 \mathrm{~V}$ peaks in Fig. 3). In Fig. 4(a), the electron concentration in the channel under the gate is strongly enhanced as compared with the doping level, and near the source the low concentration notch is formed. In Gunn diodes, the notch is made by lower doping of the region near the source. The hole concentration in the channel is lower by two orders of magnitude as compared with electron concentration and exponentially decay in source and drain contacts due to Auger recombination. Hence, the holes in Gunn-effect dynamics can be neglected. Figure 5 shows the electron accumulation layer motion in the channel.

One can see that the accumulation layer appears close to the right side of the notch and moves to the drain contact. The electron energy evolution during Gunn generation is demonstrated in Fig. 6 .

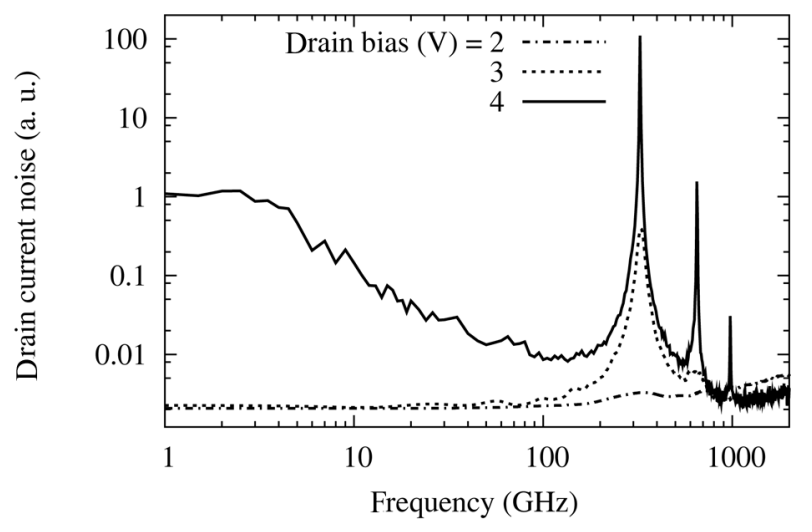

Fig. 3. Drain current noise spectral densities as functions of drain bias at $U_{\mathrm{g}}=25 \mathrm{~V}$.

The stable enhanced energy in the notch region during generation is evident. This is typical of the notched Gunn diode operation. The maximum energy and the impact ionization intensity is achieved 

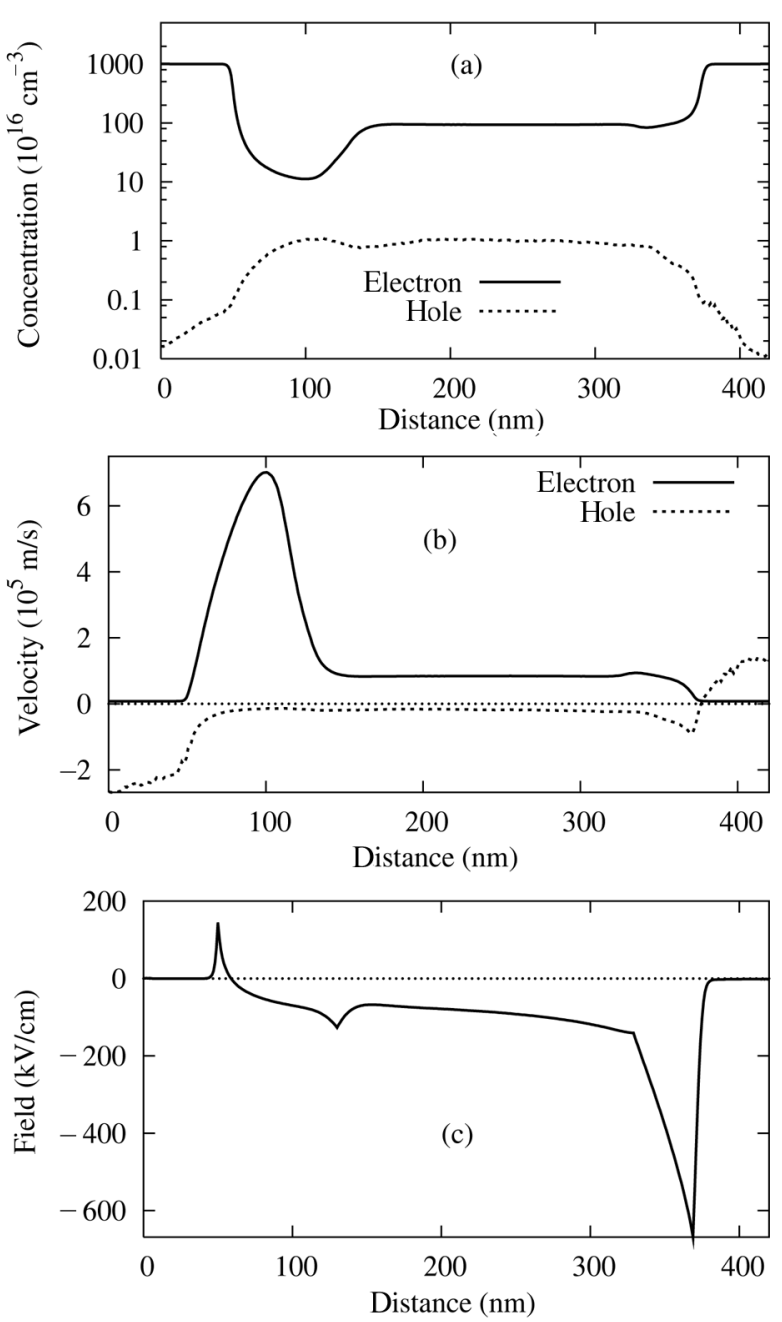

Fig. 4. Electron and hole concentration (a), velocity (b), and electric field (c) profiles at the drain bias of $4 \mathrm{~V}$ and $U_{\mathrm{g}}=25 \mathrm{~V}$.

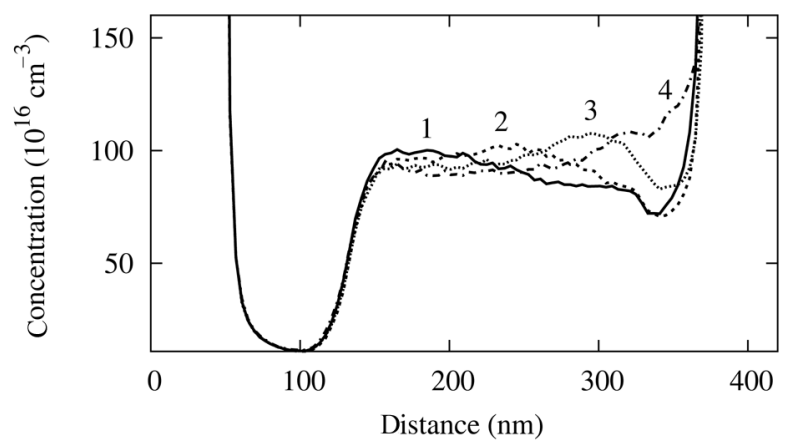

Fig. 5. Electron concentration profiles at time moments from 1 to 4 with time interval of 0.616 ps. $U_{\mathrm{d}}=4 \mathrm{~V}$ and $U_{\mathrm{g}}=25 \mathrm{~V}$.

when the accumulation layer enters the drain contact (see Figs. 5, 6). This is the reason for the drain current amplitude elevation at impact ionization conditions. Electric field profile evolution during Gunn generation is shown in Fig. 7.

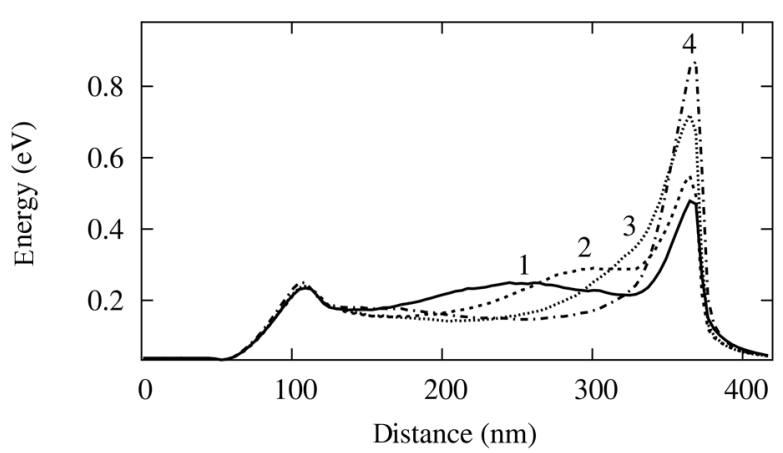

Fig. 6. Electron energy profiles at time moments from 1 to 4 with time interval of 0.616 ps. $U_{d}=4 \mathrm{~V}$ and $U_{\mathrm{g}}=25 \mathrm{~V}$.

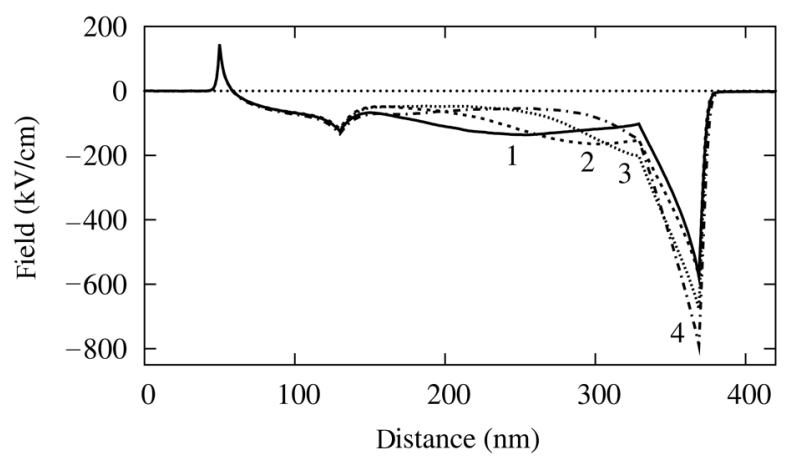

Fig. 7. Electric field profiles at time moments from 1 to 4 with time interval of 0.616 ps. $U_{\mathrm{d}}=4 \mathrm{~V}$ and $U_{\mathrm{g}}=25 \mathrm{~V}$.

Finally, the Gunn effect in field-effect transistors is the most efficient at positive gate voltages. At a positive bias, electrons from highly doped source and drain contacts are pumped under the gate leaving the lower electron concentration in not gated regions. The electron concentration in the region between the source and left edge of the gate remains stable even during Gunn generation (Fig. 5). This leads to the formation of a stable high field in this region (Fig. 7). The field launches high energy electrons into the channel under the gate facilitating the Gunn domain or accumulation layer formation. In such conditions, the $325 \mathrm{GHz}$ frequency drain current oscillations in GaAs MOSFET are simulated.

\section{Acknowledgements}

This work is supported by grant No. MIP-058/2013 of the Research Council of Lithuania.

\section{References}

[1] G.M. Dunn, G.J. Rees, and J.P.R. David, Semicond. Sci. Technol. 12, 1147-1153 (1997). 
[2] G.M. Dunn, A. Philips, and P.J. Topham, Semicond. Sci. Technol. 16, 562-566 (2001).

[3] H. Marinchio et al., Phys. Status Solidi C 5, 257259 (2008).

[4] K. Brennan and K. Hess, Solid State Electron. 27, 347-353 (1984).
[5] A. Dargys and J. Kundrotas, Handbook on Physical Properties of Ge, Si, GaAs and InP (Science and Encyclopedia Publishers, Vilnius, 1994).

[6] J.H. Zhao et al., Semicond. Sci. Technol. 15, 10931100 (2000).

\title{
THz DAŽNIO GANO EFEKTO MONTE KARLO MODELIAVIMAS GaAs MOSFET TRANZISTORIAMS SU ELEKTRONU PERTEKLIUMI KANALE SMÜGINĖS JONIZACIJOS SĄLYGOMIS
}

\author{
V. Gružinskis, E. Starikov, P. Šiktorov \\ Fiziniu ir technologijos mokslu centro Puslaidininkiu fizikos institutas, Vilnius, Lietuva
}

\begin{abstract}
Santrauka
Pateikti GaAs MOSFET tranzistorių smūginès jonizacijos kanale modeliavimo Monte Karlo metodu rezultatai. Pagrindinis dèmesys buvo kreipiamas tranzistoriaus veikimui esant teigiamai užtūros įtampai, kai elektronų koncentracija kanale po užtūra stipriai viršija kanalo legiravimo lygi. Apskaičiuotos stacionarios charakteristikos, tarp jų voltamperinès charakteristikos, greičio,
\end{abstract}

energijos ir elektrinio lauko profiliai. Taip pat pateikti santakos srovès triukšmo spektrai esant ịvairioms santakos ittampoms. Ištirta Gano efekto dinamika esant elektronų pertekliui kanale. Atlikta tranzistoriaus geometrinių, legiravimo ir elektrinių parametrų optimizacija siekiant gauti aukšto dažnio generaciją. Parodyta, kad GaAs MOSFET tranzistorius gali generuoti $325 \mathrm{GHz}$ dažniu. 